\section{The Effect of English Conversation Videos on Students' Listening Skill}

\author{
1 Arrosyi Dayana Sutrisno \\ 1. Universitas Muhammadiyah Jakarta, Indonesia
}

\begin{abstract}
The purpose of this research was to prove that using an English conversation videos is effective in teaching listening skill. This research conducted in SMP Muhammadiyah 1 Wonosobo. The population of this research is eight-grade students, and the sample is 40 students. The method of this research is quantitative method and using pre-experimental design. To collect the data, the writer used a pre-test, and post-test that given to the students. The resulting score of the data indicated that, the total score of students in the pre-test was 2350 with the average were 58.75 . The total student's post-test score is 3080 with an average of 77 . The results of the pre-test and post-test were calculated using a t-test. The calculation of the data result indicates that the t-count was 2.26 with t-table is 1.69 at the 0.05 -significance level. Therefore, this implies that the alternative hypothesis ( $\mathrm{H} 1)$ is accepted, and the null hypothesis $(\mathrm{HO})$ is rejected. The writer concluded that using English conversation videos on studies in teaching English was effective to improve students' listening skills.
\end{abstract}

\section{Keywords}

English conversation videos

listening skill

teaching listening skill

\section{Ethical Lingua}

Vol. 7, No. 2, 2020

ISSN 2355-3448 (Print)

ISSN 2540-9190 (Online)

Corresponding Email Arrosyi Dayana Sutrisno oci.dayana86@gmail.com

Article's History

Submitted 23 July 2020

Revised 22 September 2020

Revised 26 September 2020

Accepted 4 October 2020

DOI

10.30605/25409190.196

Copyright $\odot 2020$

The Author(s)

This article is licensed under CC BY-NC-SA 4.0 License

\section{(cc) EY-NC-SA}




\section{The Effect of English Conversation Videos on Students' Listening Skill}

Language is a skill that people need communicate with. Not only to communicate, but also to build relations between other countries. By using language, people can say what they want to show and share. Language is supposed to be said not written so that it becomes a form of communication between humans. As the most widely spoken language in various countries in the world, English has been regarded as the official language for use in the international world. English has been becoming a compulsory foreign language in Indonesia. It is one of the subjects that is taught since in the elementary school until university and examined in the national examination to determine students' graduations stated by Okudaira (2012).

To understand English, four language skills in English should be mastered by people. There are listening, speaking, reading, and writing. When people attempt to learn the language, they must get a language input which is in the form of listening and reading skills. Listening is key to all effective communication. It is the process that enables the listener to comprehend, determine, and identify what the speaker is saying Atiyah \& Izzah (2019). Listening is also a process that focuses on sounds, understanding the vocabulary, grammatical structure, intonation, and stress. Hadi (2020).

Listening is the active process of receiving and responding to the spoken or sometimes unspoken message. Nordquist (2017) mentioned that listening comprehension refers to "the understanding of the implication and explicit meanings of words and sentences of spoken language". Listening comprehension is more than just hearing what is said, rather it is a child's ability to understand the meaning of the words.

The teaching of listening comprehension is not easy to do, and the reason is the students do not care with what they listen to, and they do not really want to listen to material. Therefore, there are things that can really improve listening comprehension of the students, and then something interesting that can create interesting emotions. This will definitely help student English comprehension effectively. In addition, when teacher teach listening, they also use media to teach their students. Usually the teachers are difficult to choose the media that they will use to teach. In this case, the teacher usually uses video or audio to teach. When teacher use audio and video, the students can more interest and they will focus to watch or listen what the teachers teach.

English teachers should be creative in teaching English and should upgrade the method Thus, teaching method is the important thing that the teachers use in teaching. Hadi \& Rizqiningsih (2019). One of the ways to teach English to teens is using media and other learning support besides of using textbooks and other materials provided by the school. In learning language there are many various alternatives techniques and media that teachers can apply for teaching language skills especially for improving listening skill, such as using songs, podcasts, movies or videos. It can be concluded that using video in teaching listening is a good alternative. On the other hand, video can be easily accessed because it is available in a variety of forms of video tapes, DVDs, TV, online video, etc. Through video and the teacher guides, student can perform a variety of activities from reading, listening, speaking, and writing by using a wide variety of video, such as video interviews, movie 
trailers, music videos, also, English conversation videos. One of the resources we can use is YouTube videos.

Video material can be used as an alternative teaching tool for teaching listening because they are rich in English speaking and dialogue resources. This makes it easier to understand pronunciation. As a result, the use of video material is widely used as an instrument to practice listening skills in English language learning.

However, in this research the researcher used media thus can solve in the problem on listening is English conversation videos is found on YouTube related to the topic or theme of material that is taught in the 8th grade of Junior high school. The researcher argues that the use of English conversation videos is expected to help students in understanding some functional English conversation, so, learning objectives can be achieved.

\section{Method}

The research was conducted in SMP Muhammadiyah 1 Wonosobo in the academic year 2019/2020, which is located at Jl. KH. Hasyim Asy'ari No. 36 Argopeni Wonosobo, Jawa Tengah. The population of the study is the eight-grade. The total of the eight grade is 240 students. The researcher chooses a sample using cluster random sampling and the sample is a class $8 \mathrm{~A}$, which consists of 40 students. The method used in this study is quantitative.

According to Brown (2015), "quantitative approach can be defined as the research that uses numbers as data collection and the applies statistics to analyze the data". There are two variables in this study, independent variable (Variable $X$ ) and dependent variable (Variable $Y)$. Creswell (2018) states that independent variable is a variable that causes, influencing effect on the outcome. The dependent variable is a variable that depends on the independent variable. variable. The independent variable $(X)$ is the YouTube Videos and the dependent variable $(Y)$ is the students listening comprehension.

The researcher used pre-experimental design, it means that the researcher used one group pre-test and post-test. In collecting the data, both pre-test and post-test will be used as the instrument. First, the researcher gives a pre-test conducted before the implementation of the effect of English conversation on students' listening skills.

\section{Results}

The purpose of this study was to determine the effect of English conversation videos on students listening skill for $8^{\text {th }}$ grade at SMP Muhammadiyah 1 Wonosobo. The study sample of 40 students. The researcher conducts research by taking test scores (pre-test and posttest).

The student pre-test score is given by asking students to listen the videos. Then, students are asked to return to conclude what the speaker delivered. Pre-test are 20 question in form. This test is given before treatment is carried out. It is intended to find out the listening performance of students before students get treatment. Student post-test scores are given by asking students to listen the different videos. Then, they were asked to return to conclude what the speaker conveyed in the video. Post-test is 20 question in form. This test is given after the treatment is done. It was intended to determine the achievement of listening to students after students received treatment. 
Table 1. The Result of Pre-Test

\begin{tabular}{llll}
\hline CRITERIA & SCORE & $\begin{array}{l}\text { Number of } \\
\text { Students }\end{array}$ & Percentage \\
\hline Excellent & $85-100$ & 0 & 0 \\
Good & $76-84$ & 0 & 0 \\
Enough & $60-75$ & 20 & 50 \\
Poor & $40-59$ & 20 & 50 \\
Very Poor & $0-39$ & 0 & 0 \\
Total & & 40 & 100 \\
\hline
\end{tabular}

The table above shows that there were no student who got excellent, good and very poor. There were 20 students who got poor $50 \%$ of the total students fell into this category. There were 20 students who got enough result $(50 \%)$.

The researcher made a classification to students post-test result by utilizing the same measurement applied on the pre-test result. The following table shows students' listening comprehension ability according to the post-test result.

Table 2. The Result of the Post-Test

\begin{tabular}{llll}
\hline CRITERIA & SCORE & $\begin{array}{l}\text { Number of } \\
\text { Students }\end{array}$ & Percentage \\
\hline Excellent & $85-100$ & 10 & 90 \\
Good & $76-84$ & 11 & 7.5 \\
Enough & $60-75$ & 19 & 2.5 \\
Poor & $40-59$ & 0 & 0 \\
Very Poor & $0-39$ & 0 & 0 \\
Total & & 40 & 100 \\
\hline
\end{tabular}

Table 3. One-Sample Kolmogorov-Smirnov Test

\begin{tabular}{|c|c|c|c|}
\hline & & Pre-Test & Post-Test \\
\hline \multicolumn{2}{|l|}{$\mathrm{N}$} & 40 & 40 \\
\hline \multicolumn{2}{|c|}{ Normal Parameters ${ }^{\mathrm{a}}$ Mean } & 58.75 & 77.0000 \\
\hline \multicolumn{2}{|l|}{ Std. Deviation } & 9.25078 & 8.07020 \\
\hline \multirow{3}{*}{ Differences } & Absolute & .178 & .195 \\
\hline & Positive & .178 & .107 \\
\hline & Negative & -.150 & -.195 \\
\hline \multicolumn{2}{|c|}{ Kolmogorov-Smirnov Z } & 1.125 & 1.233 \\
\hline \multicolumn{2}{|c|}{ Asymp. Sig. (2-tailed) } & .159 & .096 \\
\hline
\end{tabular}

Based on the calculation table data normality, the pre-test and post-test scores showed significant (2tailed) results of $0.318>a(0.05)$ where the significance score was higher than $\alpha=0.05$. It means the data of pre-test and post-test in experimental group is normal. Therefore, the used data in this study is normal so that the data can be preceded to the next statistical test. 


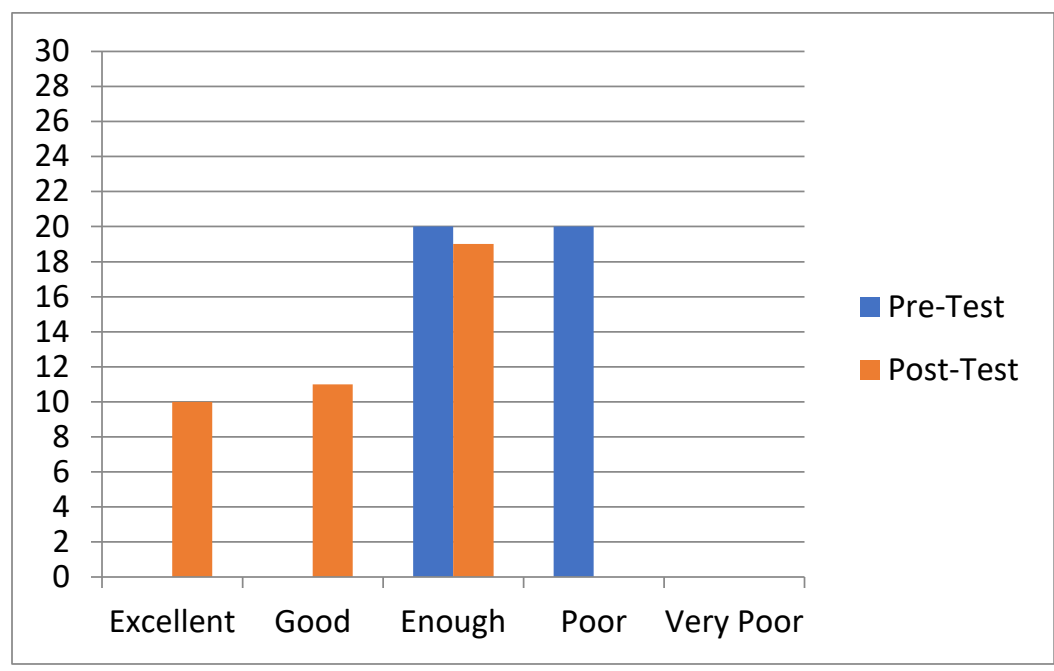

Based on the diagram above, in administering test, it reveals that 20 students were in enough criteria (50\%), 20 students were in the poor criteria (50\%), and no one student was excellent, good and very poor criteria. For post-test reveals that 10 students were in the excellent criteria (25\%), 11 students were in good criteria (27.5\%), 19 students were in enough criteria (47.5\%), and no one student was in poor and very poor criteria.

In addition, referring to the finding of score calculation using a $t$-test, the t-test calculation showed that t-calculation was 2.26 with a degree of freedom (df) of 35 . In sum, comparing to the significance level of 0.05 with $t$-table 1.69 , the data analysis finding showed that $t-$ calculation is higher than t-table. It indicates that the use of English conversation videos gives significant effect in teaching listening skill.

\section{Discussion}

From the result presented above, pre-test and post-test have significant difference score and it was proven by getting 2350 for pre-test and 3600 for post-test. The mean's pre-test score was 58.75 and mean's post-test score was 90.00 . It means that the variances of pretest and post-test are dissimilar. Additionally, based on the statistical calculation above, it can be seen that there is obvious difference between the mean score from the result of teaching listening skill using listen English conversation videos and without using it.

Based on paired Sample t-test table, t-score was 25.05, meanwhile pre-test and post-test score of the experimental class obtained the probability score or its significant (2-tailed) and it is equal 0.000 with significance level $\alpha=0.05$ (2-tailed). Since the score is $\alpha=0.05>$ 0,000 the $\mathrm{H} 1$ accepted and Ho was rejected.

There are many ways to teach listening and one of them is watching videos. Many scholars have conducted studies which applied watch video in their teaching especially in teaching listening. So, this research can be said to be successful, same as previous studies because the results of the post-test scores increase than the pre-test scores.

\section{Conclusion}

It could be concluded that the use of English conversation videos in teaching listening to the eighth-grade students was more effective. The students were able to understand the materials and improve their ability in teaching listening through video. Based on the data 
that has been taken by the researchers, the value of $t$-calculation $(0.318)$ was higher than the value of t-table (0.05) at the significance level of 0.05 . It can be concluded that the null hypothesis $(\mathrm{H} 0)$ was rejected, and the alternative hypothesis $(\mathrm{H} 1)$ was accepted. It means that by using English conversation videos can improve students' listening skills. This media gives a significant effect on the eight-grade students of SMP Muhammadiyah 1 Wonosobo.

\section{Acknowledgment}

Thanks for my beloved parents, for the unceasing encouragement, support and attention. Mr. Dr. Muhammad Sofian Hadi, M.Pd as the head of English Education Study Program at Muhammadiyah University of Jakarta. and Mr. Aswir, M.Pd as thesis supervisor.

\section{References}

Atiyah, F., \& Izzah, L. (2019). A Comparative Study on the Effectiveness of Using Direct and Audiovisual Methods for Enhancing Students Listening Comprehension. English Language in Focus (ELIF), 2(1).

Brown, H. (2015). Teaching Listening. New York: Cambridge University Press.

Creswell, J. W. (2018). Educational Research Planning, Conducting, and Evaluating Quantitative and Qualitative Research. New Jersey: Pearson Education Inc.

Hadi, M. S. (2019). The Use of Song in Teaching English for Junior High School Student. English Language in Focus (ELIF), 1(2), 107-112.

Hadi, M. S., \& Rizqiningsih, S (2019). Multiple Intelligences (MI) on Developing Speaking Skills. English Language in Focus (ELIF), 1(2). 127-136.

Nordquist, R. (2017). Listening Definition and Example in Grammar.

Okudaira, A. (2012). A Study on International Communication in Regional Organizations: The Use of English as the "official" Language of the Association of Southeast Asian Nations (ASEAN). Asian Englishes, 2(1), 91-107. https://doi.org/10.1080/13488678.1999.10801020 